\title{
Implementasi Kompetensi Pedagogik Guru Dalam Mengelola Pembelajaran Di SD Negeri 2 Fajar Indah Kabupaten Bangka Selatan
}

\author{
Jayanti Mandasari'1, Edi Waluyo², Eva Harista ${ }^{3}$ \\ ${ }^{1}$ IAIN Syaikh Abdurrahman Siddik Bangka Belitung \\ 2 IAIN Syaikh Abdurrahman Siddik Bangka Belitung \\ ${ }^{3}$ IAIN Syaikh Abdurrahman Siddik Bangka Belitung
}

Info Artikel : (9 pt)

Diterima 3 Januari 2020

Direvisi 12 Januari 2020

publikasikan 22 Januari2020

\section{Kata Kunci:}

Kompetensi pedagogik

guru

mengelola pembelajaran

Keywords:

Pedagogical competence

teacher

managing learning

\begin{abstract}
ABSTRAK
Diambilnya permasalahan ini berdasarkan pertimbangan bahwa saat ini sangat dibutuhkan seorang guru yang memiliki kompetensi pedagogik yang baik sehingga dapat mengimplementasikan kompetensi yang dimiliki di sekolah dengan baik. Dari apa yang dilakukan guru-guru di SD Negeri 2 Fajar Indah menggambarkan bahwa implementasi dari kompetensi pedagogik guru berjalan sesuai dengan yang diharapkan. Jenis penelitian ini adalah penelitian lapangan yang dianalisis secara deskriptif kualitatif. Hasil penelitian ini menunjukkan bahwa implementasi kompetensi pedagogik guru dalam mengelola pembelajaran di SD Negeri 2 Fajar Indah Kabupaten Bangka Selatan telah terlaksana dengan cukup baik. $\mathrm{Hal}$ ini berdasarkan adanya indikator kompetensi pedagogik guru yang belum dilaksanakan dengan baik oleh beberapa guru di kelas: pertama kurangnya pemahaman guru dalam pengaturan kelas berdasarkan karakteristik peserta didik, kedua kurangnya pemahaman guru pada indikator pengaturan proses pembelajaran dan aktivitas yang bervariasi, ketiga guru menyusun silabus sesuai dengan tujuan kurikulum, keempat guru belum melakukan aktivitas pembelajaran secara bervariasi dan kurang memanfaatkan alat bantu mengajar, kelima guru menanggapi setiap pertanyaan dari peserta didik dengan tepat dan efektif. Keenam, penilaian yang sudah disusun serta dilaksanakan oleh setiap guru. Ketujuh, terbatasnya jenis ekstrakurikuler di sekolah. Faktor pendukung implementasi kompetensi pedagogik diantaranya pengalaman guru, disiplin, pengembangan kompetensi guru.
\end{abstract}

\section{ABSTRACT}

this problem based on the consideration that currently very needed a teacher who has good pedagogical competence so that he can implement the competencies held in school properly. From what teachers do at SD Negeri 2 Fajar Indah illustrates that the implementation of the teacher's pedagogical competencies runs as expected. This type of research is field research analyzed descriptively qualitatively. The results of this study indicate that the implementation of the pedagogical competence of teachers in managing learning in SD Negeri 2 Fajar Indah, South Bangka Regency has been implemented quite well. This is based on the existence of teacher pedagogical competency indicators that have not been implemented well by some teachers in the class: firstly the lack of teacher understanding in classroom settings based on student characteristics, secondly the lack of teacher understanding of indicators of learning process arrangements and varied activities, all three teachers arrange syllabus according with curriculum objectives, the four teachers have not varied their learning activities and are not utilizing teaching aids, the five teachers respond to each question from students appropriately and effectively. Sixth, assessments that have been prepared and carried out by each teacher. Seventh, the limited types of extracurricular activities in schools. Supporting factors for the implementation of pedagogical competencies include teacher experience, discipline, and teacher competency development.

This is an open access article distributed under the Creative Commons Attribution License, which permits unrestricted use, distribution, and reproduction in any medium, provided the original work is properly cited. (C)2019 by author. 


\section{Pendahuluan}

Pendidikan memiliki kedudukan penting bagi individu maupun kemajuan masyarakat, karena itu maka permasalahan pendidikan begitu menarik untuk diperhatikan. Pendidikan di Indonesia bagi Negara tetangga pernah menjadi kiblat pendidikan, negara tetangga Malaysia merupakan salah satu contohnya. Pendidikan di Malaysia cukup jauh tertinggal dari Indonesia beberapa tahun lalu. Sekitar tahun 19601970an bahkan Indonesia mengirimkan cukup banyak tenaga pengajar/guru berkualitas ke Malaysia. Namun selain itu Malaysia pun mengirimkan putra-putri berkualitasnya untuk berguru ke Indonesia. Tetapi seiring berjalannya waktu, kualitas pendidikan di Indonesia tampaknya berjalan di tempat, bahkan dapat dikatakan cenderung mundur. ${ }^{1}$ Saat ini yang terjadi justru sebaliknya, Malaysia tidak lagi mengimpor guru ataupun mengirimkan para siswanya untuk belajar ke Negara Indonesia namun saat ini Indonesi yang justru belajar ke Malaysia.

Rendahnya mutu pendidikan menjadi isu yang harus mendapat perhatian serius dari segenap pemangku kebijakan pendidikan. Di kawasan Asia Tenggara mutu pendidikan kita masih terpuruk jika dibandingkan dengan negara-negara lain seperti Malaysia dan Thailand. Permasalahan pendidikan begitu menarik untuk dicermati dalam hal ini, sebab pendidikan itu memiliki nilai yang fundamental bagi kepentingan individu ataupun kemajuan masyarakat.

Lebih lanjut menurut Hamzah B. ${ }^{2}$ salah satu persoalan mendasar yang perlu mendapat perhatian dalam dunia pendidikan saat ini ialah tentang kinerja guru yang rendah dalam berbagai jenjang pendidikan, termasuk jenjang pendidikan Sekolah Dasar (SD). Hal tersebut ditunjukkan dengan belum berkembangnya seluruh kompetensi yang seharusnya dimiliki oleh guru. Padahal seyogianya seorang guru dalam proses belajar mengajar memiliki kompetensi yang baik. Sejalan dengan yang diutarakan oleh Imron bahwa seorang guru seharusnya mampu menampilkan berbagai kemampuan yaitu membuat perencanaan, melaksanakan prosedur pengajaran, dan mampu berinovasi dalam mengadakan hubungan antar pribadi, disamping itu harus mampu memanfaatkan fasilitas yang tersedia dalam proses belajar mengajarnya.

Ruang lingkup pendidikan adalah jauh lebih luas dari sekedar transfer of knowledge. Para ahli berpendapat bahwa pendidikan adalah proses membangun manusia dengan seutuhnya. Pendidikan merupakan aktivitas yang memanusiakan manusia. Hal ini berarti bahwa pendidikan merupakan upaya membantu anak untuk menemukan jati dirinya. Sekolah merupakan lembaga formal untuk menyeleggarakan pendidikan, serta tempat yang strategis untuk membentuk individu yang unggul, dan interaksi antara guru dan murid lebih dominan terjadi di ruang kelas. Maka, jika mengharapkan mutu pendidikan kita mengalami perbaikan yang signifikan, sudah saatnya perbaikan dilakukan dimulai dari ruang-ruang kelas atau sekolah. Agar dapat berkontribusi terhadap peningkatan kualitas sumber daya manusia, maka dalam pembangunan pendidikan ditentukan oleh tiga syarat utama yakni: 1) sarana gedung, 2) buku yang berkualitas, 3) guru dan tenaga kependidikan yang profesional. ${ }^{3}$ Keberhasilan peserta didik terutama dalam proses belajar mengajar sangat ditentukan guru. Sebab komponen yang paling berpengaruh terhadap terciptanya proses dan hasil pendidikan yang berkualitas yaitu seorang guru. ${ }^{4}$ Profesi sebagai guru membutuhkan keahlian dan keterampilan khusus. Oleh karenanya orang yang tidak memiliki keahlian khusus tidak dapat melakukan pekerjaan tersebut. Profesi sebagai guru memerlukan syarat-syarat khusus, terlebih lagi profesi guru profesional yang tentu harus menguasai seluk-beluk pendidikan dan pembelajaran dengan berbagai ilmu pengetahuan. ${ }^{5}$

Lebih lanjut, guru sebagai orang yang memiliki wewenang dan tanggung jawab terhadap pendidikan siswa, baik secara individual maupun secara klasikal baik di sekolah maupun di luar sekolah minimal harus memiliki dasar-dasar kompetensi sebagai wewenang dalam menjalankan tugasnya. Karena kompetensi mengajar harus dimiliki oleh seorang guru yang merupakan kecakapan atau keterampilan dalam mengelola kegiatan pendidikan. ${ }^{6}$

Guru diharuskan memiliki kompetensi dalam melaksanakan proses pembelajaran dengan sebaikbaiknya. Seorang guru harus mempunyai kualifikasi akademik, kompetensi, sertifikat pendidik, sehat jasmani dan rohani, serta memiliki kemampuan untuk mewujudkan tujuan pendidikan nasional. Guru yang kompeten lebih mampu mengelola kelasnya, sehingga kegiatan belajar mengajar peserta didik data berjalan lebih optimal.

Undang-undang nomor 14 tahun 2005 tentang guru dan dosen, menjelaskan bahwa: kompetensi adalah seperangkat pengetahuan, keterampilan, dan perilaku yang harus dimiliki, dihayati, dan dikuasai

\footnotetext{
${ }^{1}$ Imas Kurniasih dan Berlin Sani, Sukses Uji Kompetensi Guru, (Surabaya: Kata Pena, 2015), hlm.1.

${ }^{2}$ Hamzah B. Uno dan Nina Lamatenggo, Tugas Guru dalam Pembelajaran, (Jakarta: Bumi Aksara, 2016 ), hlm. 6.

${ }^{3}$ E. Mulyasa, Menjadi Guru Profesional, (Bandung: PT Remaja Rosdakarya, 2005), hlm. 3.

${ }^{4}$ E. Mulyasa, Standar Kompetensi dan Sertifikasi Guru (Bandung: Remaja Rosdakarya, 2007), hlm. 5.

${ }^{5}$ Jamil Suprihatiningrum, Guru Profesional, (Yogyakarta: Ar-Ruzz Media, 2016), hlm. 23.

${ }^{6}$ Imas Kurniasih dan Berlin Sani, Sukses Uji..., hlm. 73.
} 
oleh guru atau dosen dalam melaksanakan tugas keprofesionalan. ${ }^{7}$ Peraturan Menteri pendidikan nasional nomor 16 tahun 2007 tentang standar kualifikasi akademik dan kompetensi guru menyebut macam-macam kompetensi yang harus dimiliki oleh tenaga guru. Kompetensi yang dimaksud adalah mencakup empat hal, antara lain: kompetensi pedagogik, kompetensi kepribadian, kompetensi profesional, dan kompetensi sosial. Keempat kompetensi tersebut terintegrasi dalam kinerja guru.

Kompetensi pedagogik merupakan salah satu dari beberapa kompetensi yang harus dimiliki oleh seorang guru. Guru dalam kompetensi ini diharuskan dapat memahami peserta didiknya serta memahami bagaimana memberikan pada siswanya suatu pengajaran yang benar. Kompetensi pedagogik adalah kemampuan mengelola pembelajaran peserta didik yang meliputi pemahaman terhadap peserta didik, kemudian perancangan dan pelaksanaan pembelajaran, evaluasi hasil belajar, dan pengembangan peserta didik untuk mengaktualisasikan berbagai potensi yang dimilikinya. Demikian Penjelasan dalam Standar Nasional Pendidikan Pasal 28 ayat (3) butir a. ${ }^{8}$

Ada 7 aspek dan beberapa indikator yang berkenaan dengan penguasaan kompetensi pedagogik dalam mengelola pembelajaran, yaitu: menguasai karakteristik siswa, menguasai teori belajar dan prinsip- prinsip pembelajaran yang mendidik, pengembangan kurikulum, kegiatan pembelajaran yang mendidik, pengembangan potensi peserta didik, komunikasi dengan peserta didik, dan penilaian serta evaluasi. Masing-masing aspek memiliki indikator yang berbeda. Ketujuh aspek tersebut harus dikuasai dan diimplementasikan oleh seorang guru di sekolah agar proses belajar mengajar dapat tercapai dengan baik.

Pendidikan di Indonesia hanya menempati peringkat ke-10 dari total 14 negara berkembang. Sedangkan komponen penting dalam pendidikan yaitu guru menempati urutan ke-14 dari 14 negara berkembang di dunia, demikian menurut data dari UNESCO dalam Global Education Monitoring (GEM) Report 2016. Besarnya anggaran pendidikan pun tidak menjadikan kualitas pendidikan meningkat, Kualitas pendidikan di Indonesia masih jauh dari memadai. Hal ini ditunjukkan dengan hasil Uji Kompetensi Guru (UKG) tahun 2015, rata-rata nasional hanya 44,5 jauh di bawah nilai standar 75 . Bahkan kompetensi pedagogik, yang menjadi kompetensi utama guru pun belum menggembirakan. Masih banyak guru yang cara mengajarnya kurang baik, dan ada yang cara mengajar di kelasnya membosankan. Pemilihan SD Negeri 2 Fajar Indah Kabupaten Bangka Selatan sebagai tempat penelitian ini dikarenakan semua guru yang mengajar di sekolah tersebut berstatus sarjana pendidikan dan telah memenuhi kualifikasi akademik berdasarkan data yang peneliti peroleh dari sekolah tersebut.

Berdasarkan pengamatan yang peneliti lakukan dan keterangan dari guru terdapat masalah yaitu belum bervariasinya metode yang digunakan oleh sebagian guru kelas. Metode yang lebih dominan adalah ceramah sehingga pembelajaran di kelas kurang menarik. Selain itu guru masih cenderung belum memanfaatkan sumber belajar selain dari buku, menjadikan buku sebagai satu- satunya pegangan dan acuan bagi siswa dalam pembelajaran di kelas. Kemudian dalam proses pembelajaran masih terdapat guru yang menganggap bahwa peserta didik memiliki karakteristik yang sama, sehingga guru kurang memahami kekurangan dan kelebihan yang dimiliki peserta didik. Sebagai contoh tidak adanya pengaturan tempat duduk siswa berdasarkan kelebihan dan kekurangan fisik berupa tinggi badan siswa secara khusus, sehingga terdapat siswa dengan postur tinggi besar duduk dibagian depan, tentu posisi seperti ini sedikit banyak akan berpengaruh pada kenyamanan siswa lainya yang duduk dibagian belakang sebab agak terhalang. Pengembangan potensi peserta didik tampak belum maksimal, ini ditandai dengan sedikitnya kegiatan yang memicu munculnya prestasi siswa seperti sedikitnya ekskul sekolah, yaitu hanya terdapat ekskul pramuka. Komunikasi dengan peserta didik berjalan seperti biasa, santun, dan empatik. Terkait pengembangan kurikulum, guru sudah terbiasa dan mampu menyusun silabus. Sedangkan penilaian dan evaluasi belajar telah biasa dilaksanakan, seperti evaluasi hasil ujian sekolah.

Beragamnya kondisi di atas termasuk dalam indikator kompetensi pedagogik guru yaitu: pertama, menguasai karakteristik peserta didik, dalam hal ini seharusnya setiap guru mampu mencatat dan menggunakan informasi tentang karakteristik peserta didik untuk membantu proses pembelajaran. Kedua pada indikator menguasai teori belajar dan prinsip- prinsip pembelajaran yang mendidik, indikator ini membuat guru mampu menetapkan berbagai pendekatan, strategi, metode, dan teknik pembelajaran yang mendidik secara kreatif sesuai dengan standar kompetensi guru. Ketiga, pengembangan potensi peserta didik untuk mengaktualisasikan potensi yang dimiliki, dalam hal ini guru mengidentifikasi pengembangan potensi peserta didik melalui program yang mendukung siswa mengaktualisasi potensi mereka. Keempat pengembangan kurikulum, memang sudah seharusnya guru mampu menyusun silabus sesuai dengan kurikulum. Kelima kegiatan pembelajaran yang mendidik yang menyesuaikan dengan kebutuhan peserta didik. Keenam komunikasi dengan peserta didik dengan efektif, empatik dan santun, dan ketujuh penilaian dan evaluasi. Guru melakukan penilaian proses dan hasil belajar peserta didik.

${ }^{7}$ E. Mulyasa, Standar Kompetensi dan Sertifikasi Guru...., hlm.25.

${ }^{8}$ Ibid.hlm.75. 
Berdasarkan uraian di atas, maka rumusan masalah yang hendak diteliti dalam penelitian ini adalah sebagai berikut:

1. Bagaimana implementasi kompetensi pedagogik guru dalam mengelola pembelajaran di Sekolah Dasar Negeri 2 Fajar Indah Kabupaten Bangka Selatan?

2. Apa saja faktor pendukung dan penghambat implementasi kompetensi pedagogik guru dalam mengelola pembelajaran di SD Negeri 2 Fajar Indah Kabupaten Bangka Selatan?

Sedangkan tujuan dari penelitian ini yaitu untuk mengetahui implementasi kompetensi pedagogik guru dalam mengelola pembelajaran di SD Negeri 2 Fajar Indah dan untuk mengetahui apa saja faktor pendukung dan penghambat implementasi kompetensi pedagogik guru di SD Negeri 2 Fajar Indah Penelitian ini diharapkan dapatmemberikan manfaat sebagai berikut:

1. Secara teoritis penelitian ini diharapkan dapat memberikan daya guna secara teoritis bagi kepentingan akademis berhubungan dengan kompetensi pedagogik guru dalam mengelola pembelajaran terutama dalam bidang ilmu pendidikan

2. Secara praktis hasil penelitian ini memberikan informasi dan masukan bagi kepala sekolah untuk meningkatkan kompetensi pedagogik guru dalam mengelola pembelajaran

\section{Metode}

\section{Jenis Penelitian}

Jenis penelitian ini jika dilihat dari sumber datanya merupakan jenis penelitian lapangan (field research). Penyusunan karya ilmiah ini dibutuhkan data yang diperoleh dari lapangan. Penelitian ini menggunakan metode penelitian kualitatif berdasarkan jenis pengumpulan datanya. Penelitian yang menghasilkan data deskriptif dalam bentuk kata-kata atau lisan dari seseorang dan perilaku yang diamati inilah yang disebut dengan penelitian kualitatif. ${ }^{9}$ Dikutip dari Nawawi, Hamid Darmadi ${ }^{10}$ menyebutkan bahwa metode deskriptif dapat diartikan sebagai suatu prosedur pemecahan masalah yang diselidiki dengan menggambarkan atau melukiskan keadaan subjek atau objek penelitian (seseorang, lembaga, masyarakat dan lain-lain) pada saat sekarang berdasarkan fakta-fakta yang tampak atau sebagaimana adanya.

2. Lokasi

a) Lokasi Penelitian

Penelitian dilakukan di SD Negeri 2 Fajar Indah yang beralamat di Kecamatan Pulau Besar, Kabupaten Bangka Selatan, Provinsi Kepulauan Bangka Belitung.

b) Sumber Data

Sumber data merupakan komponen terpenting dalam penelitian. Sumber data yang dimaksud adalah semua informasi baik yang merupakan benda nyata, sesuatu yang abstrak, peristiwa atau gejala. Karena dari sumber data itulah semua data yang diperlukan dalam penelitian dapat diperoleh. ${ }^{11}$ Dalam penelitian ini ada dua macam sumber data, yaitu sumber primer dan sumber sekunder.

1) Sumber Primer

Sumber data primer adalah data yang dikumpulkan atau didapat oleh peneliti secara langsung dari sumber data pertama yaitu informan atau orang yang dimintai informasi terkait permasalahan yang diteliti. Penelitian ini yang akan menjadi informan atau sumber primer "Implementasi Kompetensi Pedagogik Guru dalam Mengelola Pembelajaran di SD Negeri 2 Fajar Indah Kabupaten Bangka Selatan" adalah orang-orang yang peneliti anggap kompeten dan menguasai situasi di lapangan, seperti: guru kelas atau guru berbagai bidang studi, baik umum maupun guru bidang studi Pendidikan Agama Islam (PAI).

2) Sumber Sekunder

Sumber data sekunder adalah data yang diperoleh dari sumber kedua (bukan orang pertama, bukan asli) dan merupakan sumber data pendukung. ${ }^{12}$ Data sekunder dapat diperoleh dari berbagai sumber seperti dari buku, dokumentasi, profil sekolah, laporan, jurnal, skripsi, internet serta data-data SD Negeri 2 Fajar Indah.

3. Teknik Pengumpulan Data

berikut:

Penelitian ini menggunakan beberapa teknik dalam proses pengumpulan data, yaitu sebagai

a. Observasi (pengamatan)

\footnotetext{
${ }^{9}$ Lexy J Moleong, Metodologi Penelitian Kualitatif, (Bandung: Remaja Rosdakarya, Cet. Kedelapan belas, 2004 ), hlm. 3.

10 Hamid Darmadi, Metode Penelitian Pendidikandan Sosial (Teori Konsep dan Implementasi), (Bandung: Alfabeta,2014), hlm. 184 .

11 Sukandarrumidin, Metodologi Penelitian, (Yogyakarta: Gadjah Mada University Press, 2006), hlm. 44.

12 Muhammad Idrus, Metode Penelitian Ilmu Sosial Pendekatan Kualitatif dan Kuantitatif, (Yogyakarta: Erlangga,2009), hlm. 86.
} 
Sugiyono ${ }^{13}$ mengutip pernyataan Nasution tentang observasi, observasi adalah dasar semua ilmu pengetahuan. Para ilmuan hanya dapat bekerja berdasarkan data, yaitu fakta mengenai dunia kenyataan yang diperoleh melalui observasi. Beberapa informasi yang diperoleh dari observasi adalah ruang (tempat), pelaku, kegiatan, objek, perbuatan, kejadian atau peristiwa, waktu, dan perasaan. Observasi dilakukan dengan alasan untuk menyajikan gambaran realistis perilaku atau kejadian, untuk menjawab pertanyaan, untuk membantu mengerti perilaku manusia dan untuk evaluasi yaitu melakukan pengukuran terhadap aspek tertentu melakukan umpan balik terhadap pengukuran tersebut.

Observasi dilakukan bertujuan untuk melihat bagaimana proses kegiatan. Dalam penelitian ini, peneliti menggunakan observasi non partisipan. Observasi non partisipan merupakan observasi di mana peneliti tidak setiap hari memasuki lingkungan atau situasi sosial. Hal ini dikarenakan peneliti tidak ingin kehadiran peneliti membuat kegiatan di situasi sosial tersebut berjalan tidak sebagaimana mestinya, dengan kata lain peneliti lebih menginginkan situasi yang bersifat natural, tanpa campur tangan peneliti.

b. Wawancara

Wawancara adalah percakapan dengan maksud tertentu. Percakapan itu dilakukan oleh dua pihak, yaitu pewawancara (interviewer) yang mengajukan pertanyaan dan yang diwawancarai (interview) yang memberikan jawaban atas pertanyaan itu. Metode wawancara yang digunakan peneliti dalam penelitian ini adalah wawancara semiterstruktur (semistructure interview), menurut Sugiyono, jenis wawancara ini termasuk dalam kategori in depth interview, di mana dalam pelaksanaannya lebih bebas bila dibandingkan dengan wawancara terstruktur. ${ }^{14}$

Metode ini digunakan peneliti untuk menanyakan masalah yang telah dipersiapkan, kemudian narasumber menjawab dengan bebas, dengan harapan wawancara dan data yang diungkapkan lebih rinci dan luwes. Wawancara dalam penelitian ini dilaksanakan terhadap guru yang berjumlah delapan orang, untuk mendapatkan data mengenai bagaimana implementasi kompetensi pedagogik guru dalam mengelola pembelajaran diantaranya mengenai landasan pendidikannya, pemahaman terhadap peserta didik, pengembangan kuurikulum, perancangan pembelajaran, pelaksanaan pembelajaran, pemanfaatan teknologi pembelajaran, evaluasi hasil belajar, serta pengembangan peserta didik untuk mengaktualisasikan berbagai potensi yang dimiliki.

c. Dokumentasi

Metode dokumentasi adalah metode pengumpulan data untuk mendapatkan informasi mengenai hal-hal atau variabel yang mungkin tidak didapatkan melalui wawancara atau observasi berupa catatan, buku, notulen rapat, agenda, dan sebagainya. ${ }^{15}$ Adapun menurut Patton yang dikutip oleh J.R. Raco ${ }^{16}$ dokumentasi berupa material yang tertulis yang tersimpan. Dokumentasi ini dapat berupa memorabilia atau korespondensi. Ada juga dokumentasi yang berupa audio visual.

Dalam penelitian ini, metode dokumentasi digunakan untuk memperoleh data sekunder sebagai pelengkap atau pendukung hasil data primer (observasi dan wawancara). Dokumen yang akan dikaji dianggap penting dan relevan dengan masalah yang diteliti seperti, sejarah berdirinya, visi, misi, di sekolah, dan dokumen lain yang relevan dengan topik penelitian ini.

4. Teknik Analisis Data

Pada penelitian ini teknik analisis data yang digunakan adalah model analisis interaktif dari Huberman dan Milles. Dalam teknik ini terdapat tiga komponen utama yaitu reduksi data, penyajian data dan penarikan kesimpulan yang dilakukan secara serentak dengan proses pengumpulan data selama proses penelitian. ${ }^{17}$

Data yang diperoleh melalui wawancara dan observasi dianalisis dengan menggunakan analisis deskriptif kualitatif yaitu dengan cara data yang diperoleh dari hasil observasi dan wawancara dengan informan dideskripsikan secara menyeluruh dengan mengkategorikan data-data yang berhubungan dengan implementasi kompetensi pedagogik guru dalam mengelola pembelajaran.

a. Reduksi Data

\footnotetext{
${ }^{13}$ Sugiyono, Metodologi Penelitian Pendidikan Pendekatan Kuantitatif, Kualitatif, dan R\&D, (Bandung: Alfabeta, cet. Kelima, 2008), hlm. 310 .

14 Ibid.,hlm. 230

15 Suharsimi Arikunto, Prosedur Penelitian Suatu Pendekatan Praktik, (Jakarata: PT. Rineka Cipta, 2010), hlm.274.

16 J.R. Raco, Metode Penelitian Kualitatif (Jenis, Karakteristik dan Keunggulannya), (Jakarta: Gramedia Widiasarana Indonesia, 2010), hlm. 111.

${ }^{17}$ Sugiyono, Metode Penelitian ...,hlm. 337.
} 
Reduksi data dapat diartikan sebagai proses seleksi sebagian data yang diperoleh dari catatan lapangan melalui observasi, wawancara, dan dokumentasi sebagai upaya pemusatan permasalahan yang diteliti. Mereduksi data adalah merangkum, memilih hal-hal yang pokok, memfokuskan pada hal-hal yang penting, serta dicari pola dan temanya. Dengan demikian data yang telah direduksi akan memberikan gambaran yang lebih jelas dan mempermudah penulis untuk melakukan pengumpulan data selanjutnya dan mencari lebih lanjut jika dibutuhkan. Adapun data yang akan direduksi dalam penelitian ini adalah, data penting berupa hasil observasi, wawancara, serta dokumentasi yang telah peneliti peroleh dari, guru dan pegawai yang kemudian akan peneliti pilih sesuai kebutuhan.

b. Penyajian data

Penyajian data dalam penelitian kualitatif bisa dilakukan dalam bentuk uraian singkat, bagan, dan hubungan antar kategori. Dengan penyajian data, maka akan memudahkan untuk memahami apa yang terjadi, merencanakan kerja selanjutnya berdasarkan apa yang telah dipahami tersebut. Data yang akan peneliti sajikan yaitu berupa data-data hasil wawancara, observasi, dan dokumentasi yang telah peneliti reduksi sebelumnya, yang kemudian akan disajikan dalam laporan yang sistematis dan mudah dipahami.

c. Menarik Kesimpulan/Verifikasi

Kesimpulan merupakan temuan baru yang belum pernah ada. Temuan sebelumnya dapat berupa deskripsi atau gambaran suatu objek yang sebelumnya masih remang- remang gelap sehingga setelah diteliti semakin jelas, dapat berupa hubungan kausal atau interaktif, hipotesis atau teori. Kesimpulan akan Peneliti ambil dari data yang sudah direduksi dan disajikan yakni mengenai Implementasi Kompetensi Pedagogik Guru dalam Mengelola Pembelajaran ke dalam laporan secara sistematis yang akan memperjelas hasil penelitian ini.

\section{Hasil dan Pembahasan}

Kompetensi pedagogik dalam penelitian ini terdiri dari beberapa aspek yaitu: 1. Menguasai karakteristik peserta didik, 2. Menguasai teori belajar dan prinsip- prinsip pembelajaran, 3. Pengembangan kurikulum, 4. Kegiatan pembelajaran yang mendidik, 5. Komunikasi dengan peserta didik, 6. Evaluasi hasil belajar, serta 7. Pengembangan potensi peserta didik. Implementasi kompetensi pedagogik guru dalam mengelola pembelajaran dapat dilihat dari tercapainya dan terlaksananya indikator-indikator dari aspek kompetensi pedagogik guru dalam mengelola pembelajaran.

\section{Implementasi Kompetensi Pedagogik Dalam Mengelola Pembelajaran di SD Negeri 2 Fajar} Indah

a. Menguasai Karakteristik Peserta Didik

Kemampuan guru di SD Negeri 2 Fajar Indah dalam memahami karakteristik peserta didik, dapat peneliti lihat pada saat kegiatan pembelajaran dilaksanakan oleh guru. Beberapa guru melakukan berbagai cara untuk mengenal peserta didiknya. Seperti melakukan pendekatan personal untuk mengidentifikasi masalah pada peserta didik, kemudian memberi motivasi pada peserta didik disela proses belajar mengajar di kelas. Seperti yang disampaikan oleh guru mata Pelajaran Agama Islam (PAI) yang menyatakan bahwa perlu adanya pendekatan dan memberikan arahan serta motivasi untuk mengenal karakteristik peserta didik.

Berdasarkan hasil observasi yang dilakukan peneliti dengan menggunakan lembar isian indikator variabel dalam menilai guru, dapat peneliti simpulkan bahwa secara umum guru menguasai variabel tersebut dengan cukup baik. Dari enam indikator yang ada, hanya terdapat dua indikator yang tidak terealisasi dengan baik oleh dua orang guru dari total delapan guru, yaitu pada bagian indikator pengaturan kelas untuk memberikan kesempatan belajar yang sama bagi semua peserta didik dan indikator perhatian terhada peserta didik dengan kelemahan fisik tertentu.

b. Menguasai teori belajar dan prinsip-prinsip pembelajaran

Hasil wawancara beberapa guru diantaranya menjawab bahwa mereka menggunakan berbagai strategi mengajar dan pemilihan metode yang membuat siswa aktif, seperti diskusi kelompok. Namun dari hasil pengamatan peneliti dalam proses belajar mengajar masih terdapat guru yang menggunakan metode ceramah saja, sehingga pembelajaran di kelas kurang menarik.

Berdasarkan hasil observasi yang dilakukan peneliti dengan menggunakan lembar isian indikator variabel dalam menilai guru, dapat peneliti simpulkan bahwa secara umum guru menguasai variabel tersebut dengan cukup baik. Dari enam indikator yang ada, hanya terdapat satu indikator yang tidak terealisasi dengan baik oleh tiga orang guru dari total delapan guru, yaitu pada bagian indikator guru memberi kesempatan kepada peserta didik untuk menguasai materi pembelajaran sesuai usia dan kemampuan belajarnya melalui pengaturan proses pembelajaran dan aktivitas yang bervariasi.

c. Pengembangan Kurikulum 
Berdasarkan dari data yang peneliti peroleh kemampuan guru di SD Negeri 2 Fajar Indah dalam menyusun silabus sesuai dengan kurikulum, dan merancang rencana pembelajaran sesuai dengan silabus serta memilih materi pembelajaran yang sesuai dengan tujuan pembelajaran. Dengan demikian pengembangan kurikulum di SD Negeri 2 Fajar Indah dapat dikatakan baik, kemampuan guru menyusun silabus sesuai dengan tujuan kurikulum dan menggunakan rancangan pembelajaran sesuai dengan tujuan pembelajaran.

Berdasarkan hasil observasi yang dilakukan peneliti dengan menggunakan lembar isian indikator variabel dalam menilai guru, dapat peneliti simpulkan bahwa secara umum guru menguasai variabel tersebut dengan sangat baik. Dari empat indikator yang ada semua dapat terealisasi dengan baik oleh semua guru dengan total delapan guru.

d. Kegiatan Pembelajaran yang Mendidik

Kegiatan pembelajaran yang mendidik dilaksanakan oleh para guru sesuai dengan rancangan yang telah disusun sebelumnya. Setiap guru melaksanakan aktivitas pembelajaran yang bertujuan membantu proses belajar para siswa, dan sesuai dengan kurikulum. Berdasarkan pengamatan peneliti di kelas bahwa setiap pembelajaran di kelas rata-rata siswa menggunakan buku paket sebagai sumber belajar disetiap mata pelajaran kecuali olah raga. Hal ini menunjukkan bahwa guru di sekolah tersebut kurang memanfaatkan sumber belajar lain selain dari buku paket. Padahal, sumber belajar itu banyak jenisnya dan akan membuat para siswa semakin tertarik dan semangat. Misalnya memanfaatkan audio visual termasuk TIK. Hal ini membuat aktivitas di kelas berjalan biasa saja karena fokusnya kebuku paket masing- masing, dan dapat dikatakan belum bervariasi. Guru melaksanakan aktivitas pembelajaran sesuai dengan rancangan yang telah disusun secara lengkap dan pelaksanaan aktivitas tersebut.

Berdasarkan hasil observasi yang dilakukan peneliti dengan menggunakan lembar isian indikator variabel dalam menilai guru, dapat peneliti simpulkan bahwa secara umum guru menguasai variabel tersebut dengan cukup baik. Dari delapan indikator yang ada, terdapat dua indikator yang tidak terealisasi dengan baik oleh lima orang guru dari total delapan guru, yaitu pada bagian indikator Beberapa guru belum melakukan aktivitas pembelajaran secara bervariasi dan indiktor Guru kurang memanfaatkan/menggunakan alat bantu mengajar, audio-visual termasuk TIK untuk meningkatkan motivasi belajar peserta didik dalam mencapai tujuan pembelajaran.

e. Pengembangan Potensi Peserta Didik

Menciptakan kondisi yang sedemikian rupa agar berbagai potensi dan kemampuan yang beragam bagi siswa itu dapat dikembangkan secara optimal merupakan tugas seorang guru. Untuk mengambangkan kemampuan, potensi, bakat atau minat siswa salah satu wadahnya ialah melalui kegiatan-kegiatan ekstrakurikuler. Pengembangan peserta didik untuk mengaktualisasikan berbagai potensi yang dimiliki di SD Negeri 2 Fajar Indah dapat peneliti lihat adanya kegiatan eksktrakurikuler yang diadakan oleh sekolah, diantaranya pramuka, bela diri.

Berdasarkan hasil observasi yang dilakukan peneliti dengan menggunakan lembar isian indikator variabel dalam menilai guru, dapat peneliti simpulkan bahwa secara umum guru menguasai variabel tersebut dengan sangat baik. Dari tujuh indikator yang ada semua dapat terealisasi dengan baik oleh semua guru dengan total delapan guru. Namun, terdapat masalah berupa keterbatasan jenis ekstrakurikuler di sekolah. Sebaiknya kegiatan yang ada di sekolah itu beragam, agar para siswa dapat memilih sesuai dengan minat, bakat yang dimiliki. Jika kegiatannya terbatas maka akan ada beberapa bakat, minat atau potensi siswa yang tidak tersalurkan.

\section{f. Komunikasi dengan Peserta Didik}

Berdasarkan hasil observasi di kelas pada saat kegiatan belajar mengajar berlangsung setiap guru menyampaikan materi pada peserta didik kemudian guru akan bertanya pada peserta didik tentang pemahaman mereka terhadap materi yang disampaikan. Namun dibeberapa kelas masih terdapat peserta didik yang malu bertanya, atau tidak ada yang mengajukan pertanyaan, dan di kelas yang lain ketika ada siswa yang bertanya maka guru di kelas menanggapi dengan tepat, dan terkadang membantu memperjelas pertanyaan yang dimaksud siswa.

Menurut pernyataan guru kelas 3 bahwa terkadang ketika ada materi baru yang disampaikan dan membuat siswa menarik maka akan banyak siswa yang bertanya atau sekedar memastikan rasa penasaran siswa, maka pada saat itu akan terjadi sedikit keributan di kelas, dan menurutnya ia akan bersikap tegas dan memberikan perhatian pada siswa.

Berdasarkan hasil observasi yang dilakukan peneliti dengan menggunakan lembar isian indikator variabel dalam menilai guru, dapat peneliti simpulkan bahwa secara umum guru menguasai variabel tersebut dengan sangat baik. Dari enam indikator yang ada semua dapat 
terealisasi dengan baik oleh semua guru dengan total delapan orang guru, hal ini ditunjukkan dengan cara guru menanggapi setiap pertanyaan dari peserta didik dengan tepat dan efektif, serta perhatian dan merespon pertanyaan siswa dengan baik.

g. Penilaian dan Evaluasi

Terdapat beberapa jenis penilaian yang dilakukan oleh guru kelas di SD Negeri 2 Fajar Indah terhadap para peserta didik. Jenis penilaian yang dilakukan antara lain tes tertulis (ulangan harian, UTS, dan UAS), tes lisan, perbuatan (praktek kelompok, diskusi kelompok), portofolio. Berdasarkan hasil observasi yang dilakukan peneliti dengan menggunakan lembar isian indikator variabel dalam menilai guru, dapat peneliti simpulkan bahwa secara umum guru menguasai variabel tersebut dengan sangat baik. Dari beberapa indikator yang ada semua dapat terealisasi dengan baik oleh semua guru dengan total delapan guru., ini ditunjukkan dengan penilaian yang sudah disusun serta dilaksanakan oleh setiap guru. Kemudian hasil dari evaluasi yang telah dilaksanakan tadi mereka gunakan untuk bahan penyusunan rancangan pembelajaran yang akan ada selanjutnya.

2. Faktor Pendukung dan Penghambat Kompetensi Pedagogik Guru Dalam Mengelola Pembelajaran Guru di SD Negeri 2 Fajar Indah

a. Faktor Pendukung

1. Pengalaman mengajar

Berdasarkan data yang diperoleh menerangkan bahwa, ada 3 guru di SD Negeri 2 Fajar Indah yang sudah cukup lama mengajar, sehingga guru tersebut menjadi guru yang disukai oleh para siswa di sekolah, hal ini dapat terlihat pada saat jam belajar di kelas dimulai para peserta didik terlihat sangat antusias sekali, dan mereka merasa nyaman dengan pembawaan guru tersebut yang terlihat penyayang, sabar, mengerti kondisi siswa, dan perhatian terhadap para peserta didik.

Kemampuan guru dalam menjalankan tugas dan peningkatan kompetensi guru akan dipengaruhi oleh pengalaman guru dalam mengajar. Untuk guru yang pengalaman mengajarnya baru beberapa tahun atau belum sama sekali berpengalaman, akan terasa beda cara mengajarnya dengan guru yang sudah bertahun-tahun mengajar, sehingga semakin lama dan banyak pengalaman mengajar maka tugas guru tersebut akan semakin baik. Hadirnya guru dengan masa bakti yang telah cukup lama benar-benar memberikan sumbangsih nyata dalam hal penentuan kualitas implementasi kompetensi pedagogik dilingkungan SD Negeri 2 Fajar Indah. Hadirnya mereka juga turut berperan sebagai faktor pendukung yang tidak lagi diragukan dalam hal implementasi kompetensi pedagogik.

2. Pengembangan kompetensi

Faktor pendukung selanjutnya ialah adanya kegiatan dalam pengembangan kompetensi guru, baik yang diadakan di SD Negeri 2 Fajar Indah maupun kegiatan yang diadakan oleh pemerintah. Kegiatan tersebut diantaranya ialah rapat sekolah, supervisi oleh kepala sekolah, seminar, pelatihan, MGMP, dan lain sebagainya. Menurut kepala sekolah, dengan adanya pengembangan kompetensi guru ini maka diharapkan agar para guru dapat bermaksimal dalam mengajar, dan mengatur jalannya proses belajar mengajar di kelas, sehingga tercapai apa yang menjadi tujuan pembelajaran tersebut.

3. Pengawasan kepala sekolah

Sesuai dengan misi SD Negeri 2 Fajar Indah yaitu mewujudkan sekolah yang disiplin maka berdasarkan hasil observasi sekolah dapat dikatakan bahwa para guru disiplin dalam bekerja, hal ini terlihat pada saat para guru hadir tepat waktu, dan mengerjakan tugasnya sesuai kewajibannya masing-masing serta tugas-tugas tambahan lainnya dengan baik. Kesadaran guru yang demikian sudah menjadi bagian yang tidak terpisahkan dalam keseharian. Hadirnya keadaan yang demikian tidak bisa dilepaskan dari sosok kepala sekolah yang tentu ambil bagian sebagai pemimpin, pembimbing, dan pengawas sehingga mampu menjadi motivator agar tercipta kedisiplinan dalam lingkungan sekolah.

b. Faktor Penghambat

1. Faktor penghambat guru dalam mewujudkan kinerjanya yaitu berasal dari guru itu sendiri seperti kurangnya rasa motivasi dalam mengajar sehingga kinerja yang dihasilkanpun menjadi kurang maksimal. Kurangnya motivasi pada guru menyebabkan guru menjadi bersemangat dalam mengajar sehingga kurang efektif dalam proses mengajar.

2. Faktor yang menjadi penghambat berikutnya ialah kurang lengkapnya sarana prasarana sekolah untuk menunjang proses belajar mengajar. Berdasarkan data yang peneliti peroleh sarana yang tersedia di sekolah tersebut diantaranya ialah 3 laptop dalam kondisi baik, 
1 unit computer dalam kondisi rusak, infocus 2 unit kondisi baik, 2 sound sistem baik, 1 pengeras suara, dan 1 wireles dalam kondisi baik.

Tersedianya sarana yang memadai akan mempermudah pencapaian tujuan pembelajaran, demikian juga sebaliknya tidak tersedianya sarana yang memadai akan menberikan sumbangsih yang tidak baik bagi tercapainya tujuan pembelajaran. Demikian yang menjadi beberapa faktor penghambat jalannya implementasi kompetensi pedagogik bagi guru di SD Negeri 2 Fajar Indah.

\section{Kesimpulan}

Berdasarkan pembahasan- pembahasan di atas, penelitian ini dapat disimpulkan bahwa implementasi kompetensi pedagogik guru dalam mengelola pembelajaran di SD Negeri 2 Fajar Indah Kabupaten Bangka Selatan berdasarkan hasil wawancara, observasi terlaksana sebagai berikut. diantaranya:

1. Guru menguasai karakteristik peserta didik cukup baik, masih terdapat kekurangan dalam hal kemampuan guru yaitu pada pengaturan kelas untuk memberikan kesempatan belajar yang sama bagi semua peserta didik dan kurangnya perhatian terhadap peserta didik dengan kelemahan fisik tertentu.

2. Guru menguasai teori dan prinsip-prinsip pembelajaran cukup baik, masih terdapat guru yang belum maksimal dalam 2 indikator yaitu pada bagian indikator guru memberi kesempatan kepada peserta didik untuk menguasai materi pembelajaran sesuai usia dan kemampuan belajarnya melalui pengaturan proses pembelajaran dan aktivitas yang bervariasi.

3. Kegiatan pembelajaran yang mendidik, secara umum guru menguasai variabel tersebut dengan cukup baik, pada bagian indikator guru belum melakukan aktivitas pembelajaran secara bervariasi dan kurang memanfaatkan/menggunakan alat bantu mengajar, audio-visual termasuk TIK untuk meningkatkan motivasi belajar peserta didik dalam mencapai tujuan pembelajaran.

4. Pengembangan kurikulum, kemampuan guru menyusun silabus sesuai dengan tujuan kurikulum dan menggunakan rancangan pembelajaran sesuai dengan tujuan pembelajaran.

5. Pengembangan potensi peserta didik, dapat peneliti simpulkan bahwa secara umum guru menguasai variabel tersebut dengan sangat baik, hanya saja terbatas pada jenis eksrtakulikuler di sekolah.

6. Komunikasi dengan peserta didik, secara umum guru menguasai variabel tersebut dengan sangat baik, hal ini ditunjukkan dengan cara guru menanggapi setiap pertanyaan dari peserta didik dengan tepat dan efektif, serta perhatian dan merespon pertanyaan siswa dengan baik.

7. Penilaian dan evaluasi, secara umum guru menguasai variabel tersebut dengan sangat baik, ini ditunjukkan dengan penilaian yang sudah disusun serta dilaksanakan oleh setiap guru.

Faktor pendukung implementasi kompetensi pedagogik guru dalam mengelola pembelajaran ialah pengalaman guru, disiplin dalam bekerja, pengembangan kompetensi guru. Faktor yang menjadi penghambat kurang lengkapnya sarana prasarana sekolah untuk menunjang proses belajar mengajar, kurangnya motivasi guru, dan kurang beragamnya kegiatan ekstrakurikuler di sekolah sehingga pengembangan potensi peserta didik kurang maksimal.

\section{Referensi}

Arikunto, Suharsimi. 2010. Prosedur Penelitian Suatu Pendekatan Praktik. Jakarata: Rineka Cipta B. Uno, Hamzah dan Nina Lamatenggo. 2016. Tugas Guru dalam Pembelajaran. Jakarta: Bumi Aksara Darmadi, Hamid. 2014. Metode Penelitian Pendidikan dan Sosial (Teori Konsep dan Implementasi). Bandung: Alfabeta

Harjanto. 2010. Perencanaan Pengajaran. Jakarta: Rineka Cipta

J Moleong, Lexy. 2004. Metodologi Penelitian Kualitatif. Bandung: Remaja Rosdakarya

Kurniasih, Imas dan Berlin Sani.2015. Sukses Uji Kompetensi Guru. Surabaya: Kata Pena Mulyasa, E. 2016. Guru dalam Implementasi Kurikulum 2013. Bandung Remaja Rosdakarya

-----. 2007. Standar Kompetensi dan Sertifikasi Guru. Bandung: PT Remaja Rosdakarya

--------. 2005. Menjadi Guru Profesional. Bandung: PT Remaja Rosdakarya

Raco, J.R. 2010. Metode Penelitian Kualitatif (Jenis, Karakteristik dan Keunggulannya). Jakarta: Gramedia Widiasarana Indonesia

Sugiyono. 2008. Metode Penelitian Kuantitatif Kualitatif dan R dan D. Bandung: Alfabeta

Suprihatiningrum, Jamil. 2006. Guru Profesional. Yogyakarta: Ar- Ruzz Media

Syah, Darwin. 2007. Perencanaan Sistem Pengajaran Pendidikan Agama Islam. Jakarta: Gaung Persada Press

Undang-Undang Guru dan Dosen (UU RI No. 20 Th. 2003). 2006. Jakarta: Asa Mandiri

Usman, Moch Uzer. 2009. Menjadi Guru Profesional. Bandung: Remaja Rosdakarya

Usman, Nurdin. 2002. Konteks Implementasi Berbasis Kurikulum. Jakarta: Grasindo 